\title{
EVOLUTIONS, TRENDS AND OPTIONS REGARDING THE TOURISM ACTIVITY IN THE COVID-19 PANDEMIC CONTEXT. CASE STUDY: SĂLAJ COUNTY
}

Flaviu Doru NEAGA

University of Craiova, Romania

Email: flaviuneaga@yahoo.com

DOI: 10.52846/MNMK.19.2.06

\begin{abstract}
:
This paper presents, among other aspects, features related to tourist resources in Sălaj County, a county that, although it has some problems related to human resources due to emigration, being rich in natural beauty has a remarkable tourist potential for different types of sustainable tourism. Also, an extremely relevant analysis is performed, such as the one referring to the situation of the tourist offer, materialized in structures of tourist reception, arrivals and overnight staying, for the period 2015-2020. Following the analysis, certain recommendations are stated to improve the tourism management of the region.
\end{abstract}

Keywords: tourism, tourism development, tourism management, Sălaj county, tourist indicators

\section{Introduction}

Activities in tourism, in their great majority, are productive activities: the use of means of transport, the provision of meal and accommodation services, leisure, balneology, etc. Tourist services have certain peculiarities compared to other economic branches. These peculiarities refer to: tourist services can be evaluated only after tourists have benefited from them, because their presence is needed where the service is consumed and it cannot be delivered, as is usual with other goods. From this point of view, the tourist services have an intangible character; between the tourism activity and other branches of the economy such as construction, furniture, food, handicrafts, and so on there are close ties; As it is known, the quantity and quality of tourist products are largely determined by the demand of tourists, being influenced by the quality of goods delivered by related branches. In turn, the tourist activity is influenced and influences different economic branches, there being an interdependence between them; tourism, through its activities, capitalizes on the entire tourist range in a certain area, namely: tourist reception services, general infrastructure, people's work, physical-geographical conditions, cultural-historical objectives, etc.; tourist activities are somewhat inelastic, because the structures of receiving tourists, treatment, food, leisure, cannot be changed in a short time as some tourists would like; Within the tourist products there is also a high degree of risk regarding their realization. A stay planned for a certain period may be cancelled due to objective reasons. The consequences of this 
cause can be multiple, such as not occupying seats in means of transport or in hotels; the demand of tourists is calculated by certain specific indicators such as the variety of tourist products, the structures of tourist reception.

Touristic area of Sălaj County includes numerous elements of the natural environment, ethnographic components, historical and cultural aspects. All these elements are tourist attractions of rare beauty and richness. The tourist activity in the county was developed after the First World War, when efforts were made in order to attract tourists from the country or from abroad. There were many enlightened people of culture, who drew attention to the picturesque places in the county that could become tourist attractions. We find out about the tourist potential of Sălaj County from a work published between the two World Wars, which presents it as follows: "There are few counties that are as rich in historical documents as in Sălaj County, from Stâna to Meseş, Traian's road, in the church from Romita, a stone with the inscription of the XIII Legion in which the Roman flag was placed, at Ortelec the most advanced observation point with an earth fortress near today's church, from Hida down on the Almaş Valley was the Roman belt, at Buciumi is located an old Roman fortress, at Cizer a wooden church handcrafted by Horea, at Ban the oldest Romanian church, at Şimleu the fortress of Bathory, at Uileac and Coşeiu old churches that used to be Catholic monasteries, in Nuşfalău a burial place from the time of the Scythians and many others. " (Revista Şcoala Noastră, 2014)

In the interwar period, the Romanian government promoted a policy of tourism development throughout the country, not only in Sălaj County. The moment from which the development of official and organized tourism beginsis represented by August 1933 when the Council of Ministers and the Ministry of the Interior addressed to the prefectures specific directives. On September 7, 1933, 13 prominent personalities of the socio-cultural and political life of Sălaj set up "A committee for tourism in Sălaj county". On this occasion, the possibilities that the county has from a tourist point of view were analyzed. The Tourism Committee identified in Sălaj County 33 localities with places and regions "of tourist, ethnic and historical interest". In order for the tourism activity in the county to function in good conditions, the Committee included another 10 members. After several actions related to the development of tourism, in the period 1933-1935 the foundations of the Sălaj County Tourist Office were constituted, which was an auxiliary and external body of the National Tourism Office. Following the establishment of this office, Zalău will become a "holiday locality", and in several localities in the county, tourist offices will be set up (Jibou, Meseşenii de Sus, Ciumărna, laz, Zăuan, Zalnoc, and so on.).

An important step in the development of Sălaj tourism was also made by the appearance of the law for the organization of tourism, in 1936. Based on this law, the Sălaj County Office is reorganized, Zalău becoming a climatic locality by decision no. 862 given by ONT in 1936. Following the elaboration of this decision, in Zalău, the tourist office already has in 1936 "two shelters, an open pavilion, $1.5 \mathrm{~km}$ of road, several banks, the installation of indication signs".

\section{Regarding the tourist resources of Sălaj County}

At the county level there are two major types of tourist resources: natural and anthropogenic.

a) natural tourist resources include: the mountainous area of the county, including the Meseş and Plopiş Mountains, suitable for hiking, adventure tourism, 
climbing, paragliding, etc .; forest and hunting fund, suitable for hunting, eco-tourism, leisure; water resources, in the form of natural and anthropogenic watercourses and lakes, suitable for fishing, recreation; agricultural resources, materialized in traditional products, fruit and vegetable areas, suitable for gastronomic tourism and agrotourism; protected areas, biodiversity, for scientific tourism, eco-tourism; mineral waters, with the role of therapists and climate, for spa and health tourism;

b) anthropic tourist resources bring together: ethnic, religious and cultural diversity (communities of Romanians, Hungarians, Roma, Slovaks, etc.); urban centers, for weekend tourism, city breaks, business tourism; traditional rural areas and ethno-folk ones, favorable to agrotourism; heritage objectives (wooden and stone churches, architectural and art monuments, archaeological remains, etc.), for cultural and religious tourism; cultural institutions (museums, memorial houses, cultural centers, libraries, ensembles, and so on.) - for cultural tourism; intangible heritage (traditions, customs, cultural events, crafts, etc.) - for cultural tourism. (Sălaj County Council, 2018)

In Sălaj County there are many tourist attractions that give visitors the opportunity to spend their free time in a pleasant and useful way, by using the healing potential, visiting cultural and historical objectives, participating in various cultural and artistic events. These tourist attractions can be classified as follows:

- attractions offered by the surrounding nature (landforms, mountains, hills, depressions, lakes and rivers, hot springs, fauna and flora of the county, nature reserves). In this sense we mention the Plopiş and Meseş Mountains, the Depression and Măgura Şimleului, Măgura Priei, Băile Boghiş and Bizuşa, Lapiş Reserve, Tusa-Barcău Reserve;

- tourist attractions resulting from human activity (various religious, historical, museums, zoos or botanical gardens, resorts). This category includes the wooden churches from Cizer, Fildu de Sus, Fodora, Porti, Cehei, Strâmba Monastery, Bic Monastery, Rus Monastery, Bobota Monastery, historical objectives Roman Camp from Porolissum, Dacidava Fortress from Şimleu to Silvaniei, Fortress Marca, Zalău Museum of History and Art, Bathory Şimleu Silvaniei Fortress and others, the main rivers being Someşul, Barcăul, Crasna Agrijul;

- tourist attractions resulting from people's way of life: festivals: Echoes of Meseşene, La Fântâna Dorului, Someş Cântecele Tale, Traditions; entertainment and leisure; sport activities; shopping activities.

\section{The evolution of tourism indicators in the COVID-19 pandemic context}

Tourism has certainly been one of the most affected economic sectors globally, as a result of the restrictions introduced during the COVID-19 pandemic, over which the travel reserve has overlapped. According to UNWTO (2020, 2020b) (United Nations World Tourism Organization), the pandemic impact has led to a $60 \%$ decrease of the number of tourists in terms of international tourism in 2020.

Romania was in line with this general trend, many reservations were cancelled, which generated significant losses to the system operators. The pandemic started in 2020 had a strong negative impact on tourism in Romania, the statistical data presented by the INS being as suggestive as possible in this regard: 917,800 arrivals were registered, which represents a decrease of $44.4 \%$ in July 2020 compared to July 2019. According to the same source, the number of overnight stays registered 
for the same period a decrease of $44.7 \%$, to $2,436,500$. Obviously, the number of foreign tourists who visited Romania registered a drastic decrease, representing only $3.3 \%$ of the total number of tourists. The average length of stay for July 2020 was also reduced by 2.7 days for domestic tourists and 2.2 days for foreign tourists. Another relevant indicator for the problems generated by the tourism pandemic in Romania is the index of net use of accommodation places, which decreased by $17 \%$ compared to July 2019 , amounting to $28.8 \%$. For agrotourism pensions, the decrease was even more consistent $(22.1 \%)$. The same data, provided by the National Institute of Statistics in December are as follows: arrivals in tourist units decreased by $59 \%$, and overnight stays by $63 \%$ in December 2020 compared to December 2019, given that foreign tourists represented only $4.8 \%$ of the total number. The average length of stay was 1.8 days for domestic tourists and 2.3 days for foreign tourists, in December 2020. At the same time, the net use index of accommodation was $17 \%$, for agrotourism pensions the indicator being quoted at $16.5 \%$. The evolution of these indicators demonstrates that the best policies and decisions to support operators in this sector have not been identified and applied at the authorities level.

The number of tourists decrease was directly translated into the financial statements of the profile companies. The losses were also supplemented by the cancellation of events with a large number of participants, festivals and fairs of various types being cancelled or, at best, postponed. The Federation of Romanian Tourism Employers (FPTR) announced in April 2020 that the unemployment rate in the field of tourism was $60 \%$ and forecast an increase of around $90 \%$, taking into account the existing situation.

Starting from the restrictions related to the abroad movement in 2020, the tourists have reoriented, there being a greater interest for trips and accommodation inside the country. Of course, appreciation refers to relative size and not to a value in absolute terms. The year 2020 was not an easy one, neither for the tourism sector, nor for each individual, the effects being felt on all aspects of the life of each citizen.

If we refer to Sălaj county, within the economic activities at the county level, tourism can be positioned based on the analysis of existing statistical data. The relevance of the analysis depends on taking into account some indicators that, on the one hand to ensure the radiography of the existing situation in the county regarding the offer of tourist reception units, and on the other hand to allow the identification of quantities that can create images related to the attractiveness of the area. In the first category were included indicators regarding the capacity and activity of tourist accommodation as a whole, respectively on the structure of tourist reception units, and the second category indicators aiming at the arrivals and overnight stays of tourists in the tourist reception structures.

Taking into account the evolution of these indicators for the period 2015-2020, the results are presented in tables 1-5. 
Table 1

Capacity and activity of tourist accommodation in Sălaj county 2015-2020

\begin{tabular}{|c|c|c|c|c|c|}
\hline \multirow[t]{2}{*}{ Year } & \multicolumn{2}{|c|}{$\begin{array}{c}\text { Tourists' accommodation } \\
\text { capacity }\end{array}$} & \multirow[b]{2}{*}{$\begin{array}{c}\text { Arrivals } \\
\text { (thousands) }\end{array}$} & \multirow[b]{2}{*}{$\begin{array}{l}\text { Overnights } \\
\text { (thousands) }\end{array}$} & \multirow[b]{2}{*}{$\begin{array}{l}\text { Indications for } \\
\text { use net capacity } \\
\text { in function (\%) }\end{array}$} \\
\hline & $\begin{array}{l}\text { Existent } \\
\text { (places) }\end{array}$ & $\begin{array}{l}\text { In function } \\
\text { (thousands - } \\
\text { days) }\end{array}$ & & & \\
\hline 2015 & 1710 & 581,6 & 38,0 & 87,5 & 15,1 \\
\hline 2016 & 1923 & 660,9 & 37,4 & 85,8 & 13,0 \\
\hline 2017 & 1918 & 651,3 & 41,8 & 93,5 & 14,4 \\
\hline 2018 & 1898 & 634,1 & 40,7 & 90,6 & 14,3 \\
\hline 2019 & 1797 & 563,6 & 46,5 & 102,2 & 18,1 \\
\hline 2020 & 1643 & 982,3 & 18,1 & 21,8 & 6,9 \\
\hline
\end{tabular}

Source: www.insse.ro, 2021 (existing accommodation capacity, on July 31)

The analysis of the first data set (table 1) shows two aspects with a high significance threshold. A first finding is that the degree of net utilization of the accommodation capacity in operation is at an extremely low level, the average of the last six years being $13.63 \%$, given that an acceptable value would be around $50 \%$, and the maximum possible, by reference to the theoretical references would approach $65-70 \%$. The explanations can be multiple, but those with obvious impact are those related to a non-performing management both at microeconomic level (at the level of each unit) and at regional level (county), due to a poor promotion of the area and the opportunities it has.

The second finding is that the effects of the pandemic on tourism are obvious, but it seems to be more acute in the statistics. If at the beginning of the pandemic the estimates according to Euromonitor in Romania, predicted in an optimistic scenario a decrease of $50 \%$ in 2020 in the number of holidays, and in the pessimistic one a decline of $61 \%$, the data show us, in Sălaj county, a little under the most dramatic scenario. The depreciation of the net capacity utilization index in operation was $61.87 \%$ in 2020 compared to 2019 . The forecasts are bleak, analysts estimate that it will take at least three years for the situation to recover, respectively the values to be close to those before the crisis.

According to table 2 the situation, at the level of the tourist reception structures, knew a relative stability, their variation being insignificant and framed on a balance level. In the dynamic series, the highest increase is recorded in 2017 , of $+8.1 \%$, and the largest decrease is $-2.54 \%$ in 2019 .

The data demonstrate the existence of an appropriate number of tourist reception structures, the main challenge in the management of these units being related to ensuring normal operating conditions, increasing occupancy, developing the component of recreational activities associated with the tourist offer and not the of the realization of new units. 
Table 2

Tourist reception structures with tourist accommodation functions by types of structures, in Sălaj county

\begin{tabular}{|c|r|r|r|r|r|r|}
\hline \multirow{2}{*}{$\begin{array}{c}\text { Types of tourist reception } \\
\text { structures }\end{array}$} & \multicolumn{7}{|c|}{ Year } \\
\cline { 2 - 7 } & \multicolumn{7}{|c|}{2015} & 2016 & 2017 & 2018 & 2019 & 2020 \\
\cline { 2 - 7 } & \multicolumn{7}{|c|}{ UM: Number } \\
\cline { 2 - 7 } Number & Number & Number & Number & Number & Number \\
\hline Total & 103 & 111 & 120 & 118 & 115 & 113 \\
\hline Hotels & 10 & 12 & 10 & 10 & 10 & 8 \\
\hline Hostels & 1 & 2 & 2 & 2 & 2 & 2 \\
\hline Touristic villas & 2 & 2 & 2 & 2 & 2 & 3 \\
\hline Touristic lodges & 1 & 1 & 1 & 1 & 1 & 1 \\
\hline Bungalows & 50 & 50 & 50 & 50 & 50 & 50 \\
\hline Touristic houses & 2 & 2 & 2 & 2 & 3 & 3 \\
\hline Students and pre-school & 1 & 1 & 1 & 1 & $:$ & $:$ \\
\hline camps & 16 & 15 & 17 & 16 & 16 & 16 \\
\hline Tourist pensions & 20 & 26 & 35 & 34 & 31 & 30 \\
\hline
\end{tabular}

Source: Tempo-online, www.insse.ro, 2021

The COVID pandemic affected, first of all, as expected, the large tourist units, the only decrease in 2020 compared to 2019 being highlighted in the category of hotels. The costs of maintaining the activity in emergency conditions were a challenge for which no solutions were found for $20 \%$ of them.

The situation regarding the number of places accentuates the difficulties of functioning in crisis conditions. In 2020, 198 places disappeared at the level of hotel units, which represents a decrease of $-29.68 \%$. There is only one category in which the number of places has increased, in terms of tourist villas, the result being due to the only investment in the field, completed in 2020 in Sălaj County. The contribution represented to the tourist offer of the hotel county is obvious and implicitly the importance of maintaining them. A comparative analysis between hotels and agritourism pensions shows us an approximation between the accommodation capacity (92.32\%), in the conditions in which the number of tourist reception structures is 3.75 times higher (table 3 ). 
Table 3

Existing tourist accommodation capacity by types of tourist reception structures, in Sălaj county

\begin{tabular}{|c|c|c|c|c|c|c|}
\hline \multirow{4}{*}{$\begin{array}{l}\text { Types } \\
\text { of } \\
\text { tourist } \\
\text { reception } \\
\text { structures }\end{array}$} & \multicolumn{6}{|c|}{ Year } \\
\hline & 2015 & 2016 & 2017 & 2018 & 2019 & 2020 \\
\hline & \multicolumn{6}{|c|}{ UM: units } \\
\hline & units & units & units & units & units & units \\
\hline Total & 1710 & 1923 & 1918 & 1898 & 1797 & 1643 \\
\hline Hotels & 639 & 769 & 667 & 667 & 667 & 469 \\
\hline Hostels & 70 & 135 & 135 & 135 & 135 & 135 \\
\hline Touristic villas & 32 & 32 & 34 & 34 & 34 & 68 \\
\hline Touristic lodges & 20 & 20 & 20 & 20 & 20 & 20 \\
\hline Bungalows & 108 & 108 & 108 & 108 & 108 & 108 \\
\hline Touristic houses & 24 & 24 & 24 & 24 & 30 & 30 \\
\hline Students and pre-school camps & 45 & 45 & 43 & 43 & & : \\
\hline Tourist pensions & 408 & 389 & 388 & 380 & 380 & 380 \\
\hline Agrotourism pensions & 364 & 401 & 499 & 487 & 423 & 433 \\
\hline
\end{tabular}

Source: Tempo-online, www.insse.ro, 2021

Table 4

Tourists' arrivals in tourist reception structures with tourist accommodation functions, by types of structures, in Sălaj county

\begin{tabular}{|c|c|c|c|c|c|c|}
\hline \multirow{4}{*}{$\begin{array}{l}\text { Types of tourist } \\
\text { reception } \\
\text { structures }\end{array}$} & \multicolumn{6}{|c|}{ Year } \\
\hline & 2015 & 2016 & 2017 & 2018 & 2019 & 2020 \\
\hline & \multicolumn{6}{|c|}{ UM: Number of persons } \\
\hline & Number & Number & Number & Number & Number & Number \\
\hline Total Units & 37962 & 37377 & 41761 & 40738 & 46488 & 17766 \\
\hline Hotels & 19116 & 20112 & 22783 & 21166 & 23564 & 8066 \\
\hline Hostels & 466 & 876 & 1016 & 787 & 1820 & 555 \\
\hline Touristic villas & 1360 & 1391 & 1315 & 1341 & 1414 & 1129 \\
\hline Touristic lodges & 375 & 444 & 496 & 560 & 709 & 116 \\
\hline Bungalows & 2832 & 2310 & 1777 & 1314 & 820 & 554 \\
\hline Camping & : & : & : & : & $:$ & : \\
\hline Touristic houses & 57 & 123 & 48 & 61 & 100 & 146 \\
\hline $\begin{array}{l}\text { Students and pre- } \\
\text { school camps }\end{array}$ & 30 & & 20 & & : & \\
\hline Tourist pensions & 7638 & 6669 & 6912 & 8099 & 11151 & 4517 \\
\hline $\begin{array}{l}\text { Agrotourism } \\
\text { pensions }\end{array}$ & 6088 & 5452 & 7394 & 7410 & 6910 & 2683 \\
\hline
\end{tabular}

Source: Tempo-online, www.insse.ro, 2021 
As shown in Table 4, the evolution of tourist arrivals in the structures of tourist reception in Sălaj County, was hopeful, given that there is a consistency in the development of an upward trend, with a significant maximum in 2019. If the contribution of bungalows is eliminated from the analysis, the data obviously support this trend. And at the level of this indicator, the impact of the COVID-19 pandemic is devastating, the decrease being $-61.78 \%$. At the sector level, analyzes show that by 2020 Romanians have not completely lost their appetite for travel, opting more for holidays in the country, accessing destinations closer to home, family pensions, tourist villas located in isolated regions, apartments and holiday villas, with the possibility of cancelling them without penalties. The global analysis is partially supported at the level of Sălaj county where the tourist houses registered an increase of $+46 \%$, and the smallest decrease was registered on the tourist villas sector ($20.15 \%)$. However, taking into account the existing potential and the specificities of the tourist offer at county level, we can appreciate that the opportunity offered by the change of the attitude of Romanian tourists, respectively the orientation towards domestic destinations and less crowded areas, was little capitalized. For the area studied, the statistical situation shows a high availability in the periods characterized by a higher degree of demand, whether we refer to the weekend periods, to the season generally associated with holidays - summer, or holidays in general, those of winter especially.

Table 5

Overnight stays in tourist reception structures by types of structures, in Sălaj county

\begin{tabular}{|c|r|r|r|r|r|r|}
\hline \multirow{2}{*}{$\begin{array}{c}\text { Types of tourist } \\
\text { reception structures }\end{array}$} & \multicolumn{6}{|c|}{ Year } \\
\cline { 2 - 7 } & \multicolumn{7}{|c|}{2015} & 2016 & 2017 & 2018 & 2019 & 2020 \\
\cline { 2 - 7 } & Number & Number & Number & Number & Number & Number \\
\hline Total, din care: & $\mathbf{8 7 5 3 6}$ & $\mathbf{8 5 7 7 2}$ & $\mathbf{9 3 5 4 3}$ & $\mathbf{9 0 6 4 7}$ & $\mathbf{1 0 2 2 0 8}$ & $\mathbf{3 9 3 0 1}$ \\
\hline Hotels & 50459 & 52958 & 60051 & 55097 & 61851 & 21554 \\
\hline Hostels & 1056 & 2132 & 2458 & 1542 & 4412 & 1586 \\
\hline Touristic villas & 1913 & 1732 & 1725 & 1401 & 1426 & 1220 \\
\hline Touristic lodges & 375 & 625 & 614 & 677 & 830 & 116 \\
\hline Bungalows & 6257 & 5429 & 3605 & 4278 & 3286 & 667 \\
\hline Touristic houses & 84 & 426 & 196 & 61 & 152 & 390 \\
\hline Students and pre- & & & & & & $:$ \\
\hline school camps & 30 & $:$ & 60 & $:$ & 17863 & 8966 \\
\hline Tourist pensions & 13956 & 11435 & 10960 & 13237 & 176 & 4802 \\
\hline Agrotourism pensions & 13406 & 11035 & 13874 & 14354 & 12388 & \\
\hline
\end{tabular}

Source:Tempo-online, www.insse.ro, 2021

The situation of overnight stays largely overlaps with that of arrivals, which confirms a small share of business tourism in Sălaj County (table 5). The high degree of similarity between the two indicators demonstrates the need to identify the best solutions related to increasing the attractiveness of the tourist offer, given that the 
average number of overnight stays is relatively constant. For tourists arriving in the area, it is necessary to diversify the offer related to recreational activities, proposed cultural and sports events, to improve the infrastructure so that, once they arrive at their destination, there are motivating factors that will direct them to increase the number of overnight stays. The average length of a stay is as follows: $2015-2.3$ overnight stays per person, $2016-2.29$ overnight stays per person, $2017-2.23$ overnight stays per person, $2018-2.22$ overnight stays per person, $2019-2.19$ overnight stays per person, $2020-2.21$ overnight stays per person. The evolution is a constant one, with a minimal regression, which does not reach the alert level, but which must concern the management of the tourist units, in the sense of identifying the causes and implementing preventive measures to anticipate a negative evolution in the medium term.

\section{Conclusions}

Sălaj County should take advantage of the continuous development of sustainable tourism by increasing the economic level, the existence of a low level of pollution in the area, the advantages offered by the geographical space or the conservation of the cultural heritage. Identifying and launching nature-oriented tourism products could be a means of attracting an increasing number of tourists from all segments, ensuring an increase in the average length of stay.

As a first conclusion of the analysis, we can highlight the need to capitalize on all the opportunities currently available, in order to ensure an increase in the share of tourism in Sălaj County.

Another conclusion based on the interpretation of statistical data demonstrates the existence of an accommodation capacity superior to the interest shown by tourists for Sălaj County, a fact highlighted by the low occupancy rate. The causes are multiple and attributable to the various actors operating in the field of tourism. From local authorities to investors in the area, from travel agencies to employees in this sector, there is a wide room for manoeuvre that will lead to increasing the attractiveness of the area, to the superior capitalization of the anthropic and geographical potential.

Thus, we consider necessary and useful the elaboration of plans and strategies for the development of the tourism sector at county level, which would better highlight the existing potential, the real promotion of the area by participating in tourism fairs, especially nationally and internationally, organizing events in different fields with attractiveness for tourists, capitalizing on existing European funds for projects with a direct or indirect impact on tourism.

The pandemic has affected the tourism sector in such a way that it's profoundly changed the business types of the whole system. They have to adapt to the new tourists needs, with an increased attention to their health, safety and desire to catch outdoor travel so as to rediscover nature, authenticity, traditions and beautiful places.

In this sense, slow tourism seems to integrate perfectly because it allows tourists to safely explore a territory. The territory is taken into account complete, if the standard landscapes, culture, quality of life and environment represent the benefit and therefore the distinctive factor ready to promote ways of tourist development. Moreover, the slow territories place the residents at the middle of 
social capital, ready to share objectives and values, to collaborate to create a differentiated tourist offer and to supply a concrete impulse on development.

Romania, being among the countries that has suffered great losses within the tourism sector, should consider the chance within the tourism offer that is supported by the principles of sustainable tourism development, mainly through slow tourism. This kind of tourism can become one of the ways in which Romanian tourism can be stimulated. Slow tourism can contribute to restore tourism in all regions of the country. It is perfectly matched with the new trends of demand: green and open spaces, safety measures, hygiene, social distancing.

\section{REFERENCES}

Altman I. (2013), "Potenţialul turistic şi valorificarea eficientă în nord-vestul Transilvaniei (jud. Cluj şi Sălaj)", Teza de doctorat, Univ. Babes Bolyai, Cluj Napoca.

Goia I., A. (1982), Zona etnografică Meseş, Editura Sport Turism, Bucureşti.

Inspectoratul Şcolar-Casa Corpului Didactic Sălaj (2014), "Şcoala Noastră." Revistă pentru educaţie şi cultură pedagogică, nr.13-14.

Josan I. (2009), Tara Silvaniei, Studiu de geografie regională, Presa Universitară din Oradea, Oradea.

Medve A., Daraczi I., Coste G. (2011), Obiective turistice în nord-estul judeţului Sălaj, Editura Şcoala Noastră, Zalău.

Mihuţ I., Pop I., Mastan M., Lungescu D., Lazăr I., Popa M. (2003), Management general, Editura Carpatică, Cluj Napoca.

Morariu T., Sorocovschi F. (1972), Judeţul Sălaj, Editura Academiei, Bucureşti.

Neagu V. (2002), Managementul turistic şi al serviciilor turistice, Editura Silvi, Bucureşti.

Rotariu, I., (2009), Dezvoltarea Destinaţiei Turistice, Sibiu, Editura Alma Mater.

Sălaj. Monografie, (1980) - Editura Sport Turism, Bucureşti.

Ritchie, Brent J. R. and Crouch, Geoffrey I. (2003), The Competitive Destination, A Sustainable Tourism Perspective, Wallingford, Oxon: CABI Publishing.

Stăncioiu A. (1999), Diç̧ionar de terminologie turistică, Editura Economica, Bucureşti.

Stănciulescu G. (2003), Managementul operaţiilor de turism, Editura Allbeck, Bucureşti.

Stănciulescu G. (2004), Managementul turismului durabil în centrele urbane, Editura Economică, Bucureşti.

www.cjsj.ro

www.insse.ro

www.unwto.org 